\title{
KINERJA GURU DALAM PEMBELAJARAN PADA PROGRAM FULL DAY SCHOOL DI SMAN 22 MAKASSAR
}

\author{
ENDAH AYU KARTIKA, MISYKAT MALIK IBRAHIM, YUSUF TAHIR \\ Pascasarjana Universitas Islam Negeri Alauddin Makassar \\ Email: endahayukartika83@gmail.com,mikka_97@yahoo.com,yusuftahir@uin- \\ alauddin.ac.id
}

\begin{abstract}
:
This study discusses about the teachers performance in optimizing learning in the Full Day school program at SMAN 22 Makassar. This research was qualitative research. Data collection methods obtained through observation, interviews and documentation. The data was analyzed by reducing data, presenting data, verifying data, and validating data (triangulation). The result of the research showed that; the first was the teacher performance at SMAN 22 Makassar has improved such as planning, implementation and evaluation. The second was Full Day school at SMAN 22 Makassar about school schedules based on school rules. The third was Effective efforts to optimize learning are carried out by teachers and schools. The teacherteach the learning to the students, gave some motivation and learning methods. The school helps teachers by school rules, teaching and learning process (PBM picket) and controlled by hand master in the school.
\end{abstract}

Keywords: Teacher Performance, Learning, Full Day School

\section{PENDAHULUAN}

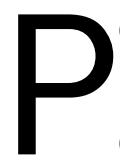

endidikan adalah sesuatu yang krusial dalam kehidupan manusia untuk menjalankan setiap aktivitasnya, mencakup persoalan individu, masyarakat dan negara. Tidak dipungkiri bahwa setiap manusia akan bersosialisasi, berorganisasi atau menjalin interaksi satu-sama lain, sehingga perlu bekal agar manusia hidup sesuai dengan tujuan Sang Pencipta yakni bertakwa kepadaNya. Realisasi ketakwaan di tengah berbagai krisis multidimensi yang melanda masyarakat membutuhkan ilmu sebagai pijakan dalam mengurai setiap masalah. Kebodohan, kemiskinan, penindasan, degradasi moral, dan penyakit sosial lainnya menjadi bagian yang harus diselesaikan untuk berlangsungnya sistem kehidupan.

Pendidikan merupakan upaya dalam mengatasi semua permasalahan tersebut maka Allah akan memberikan balasan bagi orang-orang yang berkecimpung ke dunia pendidikan dalam Q.S. Al Mujadalah, 59:11:

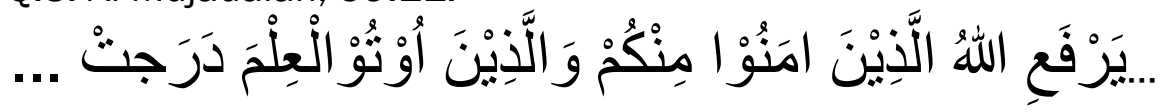

...Allah akan meninggikan orang-orang yang beriman diantaramu dan orang-orang yang diberi ilmu pengetahuan beberapa derajat... (Kementerian Agama RI, 2007).

Dalam ayat ini Allah akan meninggikan derajat orang-orang yang berilmu, karena dengan ilmunya dapat terhindar dari perbuatan yang merusak dan dapat memberikan kontribusi terbaik dalam mengatasi berbagai persoalan agar terwujud 
kecerdasan kehidupan bangsa dan negara. Orang yang berilmu berupaya menerjemahkan konsep dalam buku-buku ke realita kehidupan dengan dorongan llahi, sehingga peran ini akan menciptakan peradaban rabbani. Peradaban yang berisikan pribadi-pribadi Islam yang kompeten, kredibel, terpercaya dan berakhlak mulia karena ayat-ayat quran menjelma dalam kehidupan nyata bukan hanya sekedar dituliskan dan dihafalkan semata.

Semuanya bermuara pada pendidikan sebagai arah perbaikan generasi, sehingga dibutuhkan peran semua stakeholder mulai dari orangtua sebagai sekolah pertama bagi peserta didik, lembaga pendidikan, masyarakat dan negara. Negara memiliki peran penting dalam mewujudkan proses belajar dan mengajar yang kondusif agar terbentuk generasi unggul dan berkualitas. Pemerintah telah melakukan berbagai perubahan dan pembaharuan kebijakan dalam pendidikan seperti perubahan kurikulum namun mutu pendidikan Indonesia belum membaik. Abuddin (2003, h. 95) mengatakan hal ini ditandai dengan banyaknya pelajar berperilaku menyimpang seperti tawuran, pergaulan bebas, obat-obatan terlarang, mengikuti gaya hidup bebas di dunia barat. Banyaknya generasi terbawa arus globalisasi membuat kekhawatiran berbagai pihak sebab globalisasi bukan hanya tentang perkembangan teknologi komunikasi dan informasi, namun dapat mengundang masuknya pemahaman barat yang menawarkan kebebasan, sehingga adanya pendidikan mampu menyaring dan menjawab tantangan yang dihadapi. Alasannya, lembaga inilah yang dapat mengubah pola pikir dan pola tingkah laku peserta didik terutama dari sisi moral supaya menghasilkan lulusan yang memiliki karakter mulia dengan mengamalkan nilai-nilai Islam, sehingga memberikan kontribusi untuk negeri. Kondisi peserta didik tidak terlepas dari banyak faktor penyebabnya, salah satunya yakni kurangnya pengawasan dari orang tua. Keluarga merupakan sekolah pertama bagi terbentuknya kepribadian peserta didik, namun orang tua dituntut sibuk diluar rumah mengakibatkan menurunnya pembinaan dan pengawasan sebagai sumber terbinanya kepribadian peserta didik. Melalui pengamatan atas semua persoalan, perlu adanya kebijakan pendidikan untuk masa depan negeri yang lebih baik, hal ini tentu mengundang nalar berbagai pihak agar pendidikan di Indonesia menghasilkan lulusan yang unggul dan berkualitas serta siap menghadapi problem dan tantangan masa depan dengan karakter mulia, yaitu cerdas menyelesaikan masalah, memiliki integritas tinggi sekaligus jujur dan disiplin serta sopan santun dalam berkomunikasi dan memiliki tanggung jawab yang tinggi.

Salah satu kebijakan pemerintah melalui Peraturan Menteri Pendidikan dan Kebudayaan (Permendikbud) Republik Indonesia Nomor 23 Tahun 2017 yakni penerapan program Full Day School. Muhadjir Effendy mengungkapkan bahwa gagasan ini merujuk pada arahan Presiden untuk memperkuat pendidikan karakter peserta didik (okezone.com, 2019). Wacana ini menuai reaksi dari berbagai pihak, ada yang sepakat dan ada pula yang tidak sepakat. Ada beberapa petisi yang berisi penolakan penerapan FDS, salah satunya dari Deddy Mahyarto Kresnoputro sebagai 
orang tua siswa. Petisi dengan tema "Tolak Pendidikan Full Day/Sehari Penuh di Indonesia" ini mendapat dukungan sebanyak 47.127 pendukung (change.org, 2019). Dalam petisinya, Deddy menulis bahwa sistem belajar sekolah di negaranegara maju justru less school time, no homework, more about character building (sedikit waktu sekolah, tidak ada tugas, lebih banyak tentang pembentukan karakter). Ki Hajar Dewantara dalam Warsita dan Asrowi (2017, h. 4) mengungkapkan implementasi pendidikan karakter yakni pendidikan diterapkan untuk membantu perkembangan kehidupan anak anak. Misalnya, mengajar anakanak bagaimana cara menghormati orang tua atau orang lain, membantu dan lainlain.

Penerapan FDS tentu menjadi sebuah tantangan besar bagi sekolah khususnya para guru dalam menyiapkan pembelajaran dalam waktu yang lama agar dapat menciptakan suasana belajar yang kondusif dan inovasi. Sanjaya (2015:15) mangungkapkan bahwa dalam pembelajaran faktor yang mempengaruhi keberhasilannya yaitu faktor guru, siswa, sarana dan prasarana serta lingkungan. Kemudian, Novan (2015, h. 40) menegaskan bahwa guru merupakan ujung tombak keberhasilan pembangunan bangsa dan tokoh kunci yang menentukan keberhasilan dalam mencapai tujuan pendidikan nasional. Untuk itu, guru dituntut menjalankan tugasnya sebagai pendidik profesional dengan tugas utama mendidik, mengajar, membimbing, mengarahkan, melatih, menilai, dan mengevaluasi peserta didik pada pendidikan anak usia dini jalur pendidikan formal, pendidikan dasar, dan pendidikan menengah (Permendikbud, 2017).

Yusuf (2012, h. 81) mengatakan bahwa program peningkatan kompetensi guru tidak sepenuhnya membentuk guru pada profesionalitas yang diharapkan dan tambahan intensif tidak mendorong guru untuk memperbaiki kinerja mengajarnya. Dengan penerapan Full Day school dan kondisi guru seperti ini, maka Indonesia akan semakin mengalami kemunduran dalam bidang pendidikan, nantinya akan berdampak pada bidang-bidang yang lain, karena peserta didik itulah kelak yang mengisi posisi tersebut. Untuk mengimbangi waktu belajar Full Day school tentu akan membutuhkan kinerja guru yang maksimal dan inovasi pembelajaran apalagi dengan keadaan peserta didik cepat bosan terhadap lingkungan sekolah dan kurangnya waktu untuk mengembangkan diri, hanya anak hebat yang kuat dengan stimulus sekolah yang beragam dan mendominasi waktu sehari-harinya.

Salah satu sekolah yang mengalami masalah ini yakni SMAN 22 Makassar. Perubahan jam belajar dari 5 sampai 6 jam ke 8 sampai 9 jam belajar tiap harinya sejak tahun 2016. Sekolah tersebut memiliki akreditasi A dan telah meraih banyak prestasi di tingkat provinsi hingga internasional. Berdasarkan hasil wawancara awal yang dilakukan di sekolah, salah satu guru menyampaikan bahwa masalah yang dihadapi dalam proses pembelajaran pada program Full Day school yaitu mempertahankan konsentrasi peserta didik dalam waktu yang lama. Berkenaan dengan proses pembelajaran, pengamatan awal yang dilakukan bahwa guru 
mengalami kesulitan dalam memaksimalkan kinerja dalam pembelajaran dengan kondisi tersebut, sementara dalam UU SISDIKNAS No. 20 Tahun 2003 agar tujuan pendidikan tercapai harus menciptakan proses pembelajaran dan suasana belajar yang kondusif. Jika keadaan ini berlangsung terus-menerus maka tujuan pendidikan tidak akan tercapai. Maka dari itu, perlu ada kajian lebih dalam tentang kinerja guru dalam pembelajaran pada program Full Day school di SMAN 22 Makassar agar guru mampu memaksimalkan pembelajaran sehingga tujuan pendidikan tercapai.

\section{TINJAUAN PUSTAKA}

\section{Kinerja Guru}

Kasmawati (2014, h. 48) menjelaskan kata kinerja merupakan terjemahan dari kata "performance" yang berarti penampilan atau prestasi. Istilah ini berasal dari kata job performance atau actual performance (prestasi kerja atau prestasi sesungguhnya yang dicapai oleh seseorang). Sama dengan penjelasan Hakin (2015:3) bahwa kinerja adalah tingkat kesuksesan seseorang dalam melaksanakan suatu pekerjaan pada periode tertentu. Yaumi (2014, h. 25) menyatakan bahwa hasil yang dimaksud merujuk pada akumulasi dari tiga ranah belajar; pengetahuan, sikap dan keterampilan yang terintegrasi secara menyeluruh dalam satu kesatuan hasil yang utuh. Kinerja inilah yang akan memperlihatkan sejauh mana ilmu pengetahuan yang dimiliki seseorang. Seharusnya semakin luas ilmu pengetahuannya, maka kinerjanya akan semakin baik. Dalam proses pembelajaran, jika guru memiliki pengetahuan luas dan bertanggung jawab serta peserta didik paham urgenitas pendidikan dan siap untuk belajar, maka proses pembelajaran berlangsung optimal.

Berkaitan dengan hal itu, Sanjaya (2015, h. 26) mengungkapkan bahwa pembelajaran dapat diartikan sebagai proses kerjasama antara guru dan siswa dalam memanfaatkan segala potensi dan sumber yang ada baik potensi yang bersumber dari dalam diri siswa itu sendiri seperti minat, bakat dan kemampuan dasar yang dimiliki termasuk gaya belajar maupun potensi yang ada di luar siswa seperti lingkungan, sarana dan sumber belajar sebagai upaya untuk tujuan belajar. Pembelajaran adalah wujud dari kinerja guru, maka semua aktivitas pembelajaran dimotori oleh kemampuan guru dalam proses belajar mengajar mulai dari penguasaan bahan ajar hingga evaluasi. Jadi kinerja guru dalam pembelajaran yakni proses kerjasama antara guru dan peserta didik dengan memanfaatkan sarana dan prasarana untuk mencapai tujuan pembelajaran. Kinerja berbanding lurus dengan hasil yang dicapai dari proses belajar, artinya memperbaiki dan meningkatkan semua faktor yang mempengaruhi proses pembelajaran adalah hal penting dalam menunjang kinerja.

\section{Program Full Day School}

Kata full day school berasal dari Bahasa Inggris, terdiri dari kata full mengandung arti penuh dan day artinya hari maka full day school berarti sehari penuh (Echols dan Shadily, 1983). Sulandri (2015, h. 50) menjelaskan bahwa Full 
Day School adalah sistem belajar mengajar seharian penuh, aktifitas anak lebih banyak dilakukan di sekolah. Anak biasanya menghabiskan sekitar 6 jam perhari, tetapi dengan penerapan full day school, anak harus di sekolah sampai 9 atau 10 jam perhari.

Sistem Full Day School muncul pertama kali di Amerika yaitu di Kindergarden pada tahun 1980. Sejak itu jumlah full day school semakin bertambah dan muncul di Indonesia pada tahun 1990 namun penerapannya masih di sekolah-sekolah swasta kemudian awal tahun 2017 muncul wacana dari Menteri Pendidikan dan Kebudayaan (Mendikbud) Indonesia, Muhadjir Effendy tentang penerapan full day school untuk jenjang pendidikan baik negeri atau swasta di Indonesia. Keseriusan tersebut dibuktikan dengan terbitnya Peraturan Menteri Pendidikan dan Kebudayaan Nomor 23 Tahun 2017 tentang Hari Sekolah yakni dalam Pasal 2 ayat (1) Hari Sekolah dilaksanakan 8 (delapan) jam dalam 1 (satu) hari atau 40 (empat puluh) jam selama 5 (lima) hari dalam 1 (satu) minggu. (2) Ketentuan 8 (delapan) jam dalam 1 (satu) hari atau 40 (empat puluh) jam selama 5 (lima) hari dalam 1 (satu) minggu sebagaimana dimaksud pada ayat (1) (Permendikbud, 2017).

\section{METODE PENELITIAN}

Jenis penelitian ini adalah penelitian lapangan dengan pendekatan kualitatif. Penelitian ini berlokasi di Makassar yang merupakan salah satu sekolah yang menerapkan Full Day school yakni SMAN 22 Makassar. Sumber data diperoleh melalui wawancara dengan kepala sekolah, guru dan peserta didik SMAN 22 Makassar sebagai data primer serta observasi sebagai data sekunder.

Teknik pengumpulan data yang digunakan wawancara, observasi dan analisis dokumen. Instrumen yang digunakan adalah pedoman observasi dan pedoman wawancara. Data yang diperoleh kemudian dianalisis dengan mereduksi data, display data dan penarikan kesimpulan. Pengujian keabsahan data dengan menggunakan triangulasi teknik dan triangulasi sumber.

\section{HASIL PENELITIAN DAN PEMBAHASAN}

\section{Kinerja Guru dalam Pembelajaran pada Program Full Day School di SMAN 22 Makassar}

Guru adalah pendidik profesional dengan tugas utama mendidik, mengajar, membimbing, mengarahkan, melatih, menilai, dan mengevaluasi peserta didik pada pendidikan anak usia dini jalur pendidikan formal, pendidikan dasar, dan pendidikan menengah (Permendikbud, 2017). Secara garis besar aktivitas ini dilakukan mulai dari perencanaan, pelaksanaan, dan evaluasi peserta didik. Guru sebagai perencana sekaligus implementator pembelajaran yang berhadapan langsung dengan peserta didik yang memiliki beragam latar belakang, gaya belajar dan motivasi belajar perlu didukung oleh sarana dan prasarana serta kondisi lingkungan agar tercipta suasana belajar yang baik. 


\section{Perencanaan Pembelajaran}

Perencanaan pembelajaran merupakan rencana yang berisi langkah-langkah yang akan dilakukan pendidik dalam kegiatan belajar mengajar agar terlaksana dengan efektif. Abdul (2008, h. 6) menjelaskan bahwa perencanaan mengandung rangkaian-rangkaian putusan yang luas dan penjelasan-penjelasan dari tujuan, penentuan kebijakan, penentuan metode-metode dan prosedur tertentu dan penentuan kegiatan berdasarkan jadwal sehari-hari. Pendidik sebagai designer sekaligus implementator dalam pembelajaran maka setiap guru harus memahami urgenitas perencanaan tersebut agar kegiatan belajar mengajar terorganisir dengan baik. Langkah-langkah yang tersusun dituangkan dalam bentuk rencana pelaksanaan pembelajaran (RPP). Seorang guru harus memahami cara pembuatan RPP hingga implementasi dalam kelas. Dengan demikian, perencanaan ini merupakan proses yang harus dimulai dari tujuan yang akan dicapai melalui analisis kebutuhan kemudian menjabarkan dalam langkah-langkah yang harus dilakukan sesuai tujuan tersebut. Perencanaan ini adalah bagian awal yang cukup kritikal dan menjadi fokus perhatian seorang guru, sehingga perlu menetapkan strategi apa saja yang akan dilakukan mulai dari metode hingga taktik.

Kita mempersiapkan semua sejak awal mengacu pada rencana pelaksanaan pembelajaran sendiri, semua perencanaan ada dalam RPP yang sudah kita buat. (Wawancara dengan Rita Yuianti sebagai guru Pendidikan Agama Islam di SMAN 22 Makassar tanggal 26 September 2019)

Hal yang sama juga dikatakan oleh Ibu Vida Indriani bahwa:

Sebagai guru yang disiapkan pertama adalah RPP. Bisa kita persiapkan setahun sekali, tidak setiap hari kita buat RPP mengingat kesibukan kita. Kesiapan materi yang utama karena saya itu memberikan materi ke anakanak itu bahasanya simpel supaya mereka tidak perlu cari bimbingan belajar diluar. (Wawancara dengan Vida Indriani sebagai guru Matamatika di SMAN 22 Makassar)

Guru di SMAN 22 Makassar pada tahap perencanaan pembelajaran mengawali dengan pembuatan silabus dan RPP. Setiap awal semester guru harus mengumpulkan perangkat pembelajaran yang disesuaikan dengan kalender akademik yang ada. Perangkat pembelajaran tersebut mulai dari kalender pendidikan, perhitungan pekan efektif, program tahunan, program semester, silabus, rencana perangkat pembelajaran, analisis $\mathrm{KKM}$, jadwal tatap muka, agenda harian, absen siswa, daftar penilaian peserta didik, analisis hasil penilaian harian hingga program remedial dan pengayaan. Perencanaan yang dibuat sesuai dengan Permendikbud No. 65 Tahun 2013 tentang Standar Proses meliputi 1) identitas sekolah; identitas mata pelajaran; kelas/semester; 2) materi pokok; 3) alokasi 
waktu; 4) kompetensi inti; 5) tujuan pembelajaran; 6) kompetensi dasar; 7) indikator kompetensi; 8) materi pembelajaran; 9) metode pembelajaran; 10) media pembelajaran; 11) langkah-langkah pembelajaran; 12) sumber pembelajaran; dan 13) penilaian hasil belajar (Widarto, 2014).

Berdasarkan observasi yang dilakukan, pembuatan RPP oleh guru di SMAN 22 Makassar tidak ada pembahasan khusus tentang metode pembelajaran namun dijelaskan secara tidak langsung dalam kegiatan pembelajaran. Dalam kurikulum 13 lebih ditekankan pada student center (belajar berpusat pada peserta didik) yakni peserta didik dibuat agar aktif terlibat dalam mendapatkan materi sementara guru hanya fasilitator yang mengarahkan. Rencana pembelajaran dibuat oleh guru untuk satu pertemuan atau lebih untuk mengarahkan kegiatan pembelajaran peserta didik dalam mencapai kompetensi dasar. Setiap guru berkewajiban menyusun RPP secara lengkap dan sistematis agar proses pembelajaran berjalan dengan baik, menyenangkan dan interaktif.

Persiapan selanjutnya adalah penguasaan materi dengan baik agar peserta didik mudah memahami materi dengan kompetensi dasar yang akan dicapai. Semakin guru menguasai materi, maka guru tidak akan sulit dalam menyampaikan materi hingga maksimal hasil yang diperoleh. Guru juga mempersiapkan bahan ajar seperti powerpoint, jika praktikum maka mempersiapkan perlengkapan alat yang diperlukan dan buku apa yang akan menjadi sumber ajar serta buku cetak sebagai pegangan peserta didik. Persiapan yang dilakukan juga mematangkan metode pembelajaran di dalam kelas karena metode yang tepat dapat berpengaruh pada keefektifan belajar mengajar.

\section{Pelaksanaan Pembelajaran}

Pelaksanaan Full Day school di SMAN 22 Makassar diterapkan tahun 2016, sekitar empat tahun diterapkan dan proses adaptasi terus dilakukan hingga sekarang. Hari sekolah di SMAN 22 Makassar dari hari Senin sampai Kamis mulai pukul 07.30 sampai 16.45 dan hari Jumat mulai pukul 07.30 sampai 11.45 . Setiap hari waktu sekolah selama 8 jam 55 menit kecuali hari Jumat hanya 4 jam 15 menit. Jika diakumulasi selama seminggu waktu sekolah selama 40 jam termasuk waktu istirahatnya. Seharian penuh berada di sekolah berarti sekolah menjadi rumah kedua bagi peserta didik karena sebagian besar aktivitasnya di sekolah. Intensitas bertemu teman sekolah lebih besar daripada bertemu teman sebaya di rumah, sehingga peserta didik harus merasa nyaman berada di sekolah. SMAN 22 Makassar menerapkan beberapa pembiasan positif setiap harinya untuk membentuk kepribadian peserta didik. Membiasakan peserta didik bukan hal yang mudah bahkan pada awal penerapan Full Day school banyak keluhan dari peserta didik.

Dulu itu kami sering mengeluh kepada guru karena lelah belajar dan dituntut fokus dengan pelajaran agar paham. Kami juga dulu sering berteriak bahwa kami bukan robot, kami adalah manusia. Punya 
keterbatasan dalam belajar. (wawancara dengan Dian sebagai peserta didik di SMAN 22 Makassar tanggal 10 Oktober 2019).

Hal senada juga disampaikan oleh guru bimbingan konseling bahwa:

Saya sampaikan bahwa begini masa kalian karena masa saya jam 12 sudah pulang, mungkin ilmu kalian lebih tinggi dari ilmu saya nantinya tapi waktu belajar kalian juga terkuras disekolah dibanding saya dulu. Saya juga beri motivasi memang begitu kalau menuntut ilmu, bersusahsusah dulu nanti kita nikmati hasilnya, jalani saja dengan ikhlas dan sabar pasti akan dilewati nanti dengan tidak terasa. Tapi kalau mengeluh terus justru terasa lama, akhirnya tidak konsentrasi dan sulit menerima pelajaran dengan baik. Kalau kita ikhlas menerimanya dan menjalani dengan sabar pasti akan dijalani dengan baik. (wawancara dengan Supiyanti selaku guru bimbingan konseling di SMAN 22 makassar tanggal 10 Oktober 2019).

Keluhan yang disampaikan menandakan bahwa peserta didik tidak nyaman dan lelah dengan penerapan Full Day school sehingga peserta didik akan malas, bosan dan jenuh dalam belajar. Keadaan seperti ini tidak bisa dibiarkan begitu saja karena dapat mengurangi minat belajar dan menurunkan prestasi peserta didik. Oleh karena itu, untuk mengatasi masalah tersebut diperlukan suatu dorongan dan upaya agar peserta didik tetap bersemangat belajar. Upaya ini dilakukan dalam rangka proses pembiasaan sebab jika terbiasa, maka secara perlahan peserta didik akan menerima dan mengembalikan semangatnya dalam belajar.

Anwar (2018, h. 144) menjelaskan bahwa dua hal utama yang diperlukan untuk mencapai proses belajar mengajar yang efektif, yakni: 1) harus ada analisis kebutuhan peserta didik yaitu menganalisis hubungan antara kemampuan dan harapan peserta didik dalam proses pembelajaran; dan 2) harus ada gambaran seperti apa sistem ujian yang dipakai. Pembelajaran yang efektif harus mempunyai kesesuaian antara kebutuhan belajar dan sistem ujian peserta didik. Kenyataan yang terjadi di lapangan menunjukkan bahwa para guru terlihat akrab dengan peserta didik sehingga keluhan mudah disampaikan. Hal ini juga membantu guru dalam menganalisis kebutuhan siswa kemudian membuat keputusan apa yang akan dilakukan termasuk dalam pemberian motivasi dan metode pembelajaran serta penilaian hasil belajar.

Upaya dilakukan guru adalah mengubah pola pikir peserta didik bahwa Full Day school memberikan kesempatan untuk belajar lebih banyak dan bersosialisasi dengan teman serta guru di sekolah. Pola pikir itu yang ditanamkan agar dapat dipahami dan diimplementasikan dalam bentuk tingkah laku. Pola pikir ini juga akan mengubah sudut pandang terhadap sebuah kebijakan, sehingga kebiasaan itu dibangun atas dasar kesadaran bersama bukan sekedar taat pada aturan sekolah. 
Saya yakin setiap guru memiliki teknik dan metode masing-masing, jadi merubah metode saat melihat siswa itu mengantuk. Awal masuk kelas guru memberikan metode agar siswa itu semangatnya bangkit. Setelah istirahat yang paling rawan, Bukan hanya siswa saja tapi guru juga. Saya selaku pimpinan pada saat-saat seperti itu saya jalan diistilahkan dengan tawaf. Saya jalan keliling melihat teman-teman. Memang berat tapi kita bisa. Kalau sudah istirahat, 10 menit masuk saya jalan. Akhirnya, teman-teman bisa membangkitkan semangat. Ada guru yang meminta siswa berdiri, melakukan gerakan-gerakan supaya membangkitkan semangat atau bernyanyi dulu dua menit agar bisa konsentrasi lagi. (wawancara dengan NUr Djanni sebagai kepala sekolah SMAN 22 Makassar tanggal 9 September 2019)

Berdasarkan observasi yang dilakukan, kegiatan belajar mengajar pada siang hari merupakan waktu yang dikhawatirkan oleh guru. Ada guru yang meminta peserta didik melakukan gerakan-gerakan kecil agar tidak jenuh dalam belajar. Guru juga memvariasikan metode pembelajaran dengan metode yang berbeda-beda dalam menanamkan kompetensi dasar yang ditetapkan misalnya menggunakan metode diskusi agar peserta didik lebih interaktif dan tidak mengantuk atau metode ceramah dikombinasikan dengan tanya jawab. Selain melakukan variasi metode dikelas, guru juga melakukan variasi dengan pembelajaran diluar kelas yakni memanfaatkan halaman dan fasilitas sekolah agar peserta didik tidak bosan seharian dalam kelas. Wajar saat siang hari ada beberapa titik kumpul di halaman sekolah.

Proses pembiasaan yang dilakukan dalam kegiatan belajar mengajar tidak hanya dilakukan oleh guru namun kepala sekolah dan tenaga kependidikan ikut serta. Jika peserta didik dikontrol oleh guru dalam kelas maka guru dikontrol oleh kepala sekolah dan wakil kepala sekolah melalui piket belajar mengajar (PBM). Hal ini menunjukkan bahwa semua elemen sekolah memahami konsekuensi Full Day school dan bertanggung jawab dalam menciptakan lingkungan yang kondusif bagi peserta didik.

Cara ini diharapkan bisa membantu guru dalam proses pembelajaran dan membawa pengaruh positif baik guru atau peserta didik. Guru juga sangat terbantu dengan adanya aturan ini karena manusia tidak selalu dalam keadaan semangat terus, adakalanya menurun semangatnya. Namun perlu yang perlu diperhatikan dengan adanya aturan ini antara lain: 1) guru harus menyadari perannya sebagai ujung tombak pendidikan sehingga ketika ditegur harus menerima dengan baik; 2) alasan terlambat atau terjadi yang lain disampaikan kepada piket PBM harus dengan jelas dan benar dalam keadaan yang tidak memungkinkan untuk mengajar; 3) piket pbm harus menyadari landasan diberlakukan aturan ini agar bisa menertibkan guru dalam proses pembelajaran sehingga tidak ada unsur lain yang menjadi pertimbangan saat komunikasi dengan guru; 4) piket pbm harus dievaluasi dalam berapa bulan sekali agar bisa memberi masukan kepada guru. 
Melalui observasi dilapangan, kepala sekolah sangat tegas persoalan proses pembelajaran. Ketika ada guru yang keluar kelas saat jam belajar langsung ditegur pada saat itu. Jika ada guru tidak hadir mengajar seringkali peserta didik keluar kelas, hal ini langsung mendapat teguran dan ketua kelas dipanggil menghadap kepala sekolah. Sekolah ini memposisikan semua elemen masyarakat sekolah dan memberdayakan dengan baik agar pembelajaran berjalan dengan baik. Pada siang hari kepala sekolah melakukan tawaf keliling sekolah melihat kelas yang aktif belajar.

Pembelajaran yang profesional dapat meningkatkan pengetahuan dan katerampilan guru yang mengarah pada peningkatan pengajaran dan meningkatkan prestasi peserta didik (Elliot, 2015). Dalam hal ini kemampuan mengelola pembelajaran menjadi dasar sebagai guru yang harus dibentuk terlebih dahulu. Kinerja guru optimal jika guru mampu mengelola faktor yang memengaruhi pembelajaran dengan baik. Itu terbukti melalui pelaksanaan pembelajaran apakah sesuai dengan RPP yang telah disusun atau tidak, mulai dari pendahuluan, kegiatan inti dan penutup.

Tidak dipungkiri bahwa setiap perencanaan akan ada kendala yang dihadapi dan dikhawatirkan berdampak pada kompetensi dasar yang tidak tercapai sehingga akan mempengaruhi rancangan yang telah dibuat untuk pertemuan selanjutnya. Kendala yang biasa dihadapi guru dalam program full day scool ketika masuk kelas dengan kondisi peserta didik mengantuk saat siang hari atau belum siap belajar karena setelah olahraga. Ibu Nur djanni selaku kepala sekolah menjelaskan:

Jelas ada bedanya. terkait perbedaan itu sendiri kadang ada kelas yang tidak kondusif masih dalam keadaan ribut. Apalagi saat siang hari, biasa kelas kotor jadi harus dibersihkan dahulu. Kadang kami sudah masuk mengajar siswa baru makan karena 15 menit untuk di kantin saja kadang mereka belum sempat makan masih antri dan sebagainya. (wawancana dengan Nur Djanni selaku kepala sekolah di SMAN 22 Makassar tanggal 9 September 2019)

Upaya-upaya selalu dilakukan agar kendala tersebut tidak terjadi dilapangan sehingga pelaksanaannya berjalan sesuai dengan RPP. Berdasarkan observasi yang dilakukan, pelaksanaan pembelajaran di SMAN 22 Makassar mengacu pada RPP dan dikembangkan sesuai kondisi kelas saat kegiatan belajar mengajar. Rusman (2017:15) menjelaskan bahwa pengembangan RPP juga dapat diakukan secara mandiri atau secara berkelompok dengan prinsip-prinsip pengembangannya.

Ketika guru masuk kelas kemudian duduk dengan meletakkan perangkat pembelajaran diatas meja. Ketua kelas langsung memberi aba-aba kepada seluruh siswa untuk berdiri dan memberi salam. Guru mengabsen kehadiran siswa kemudian melakukan apersepsi dengan bertanya kepada siswa materi pembelajaran sebelumnya dan menjelaskan hubungan antara materi sebelum dengan yang akan dipelajari jika ada relasinya. Guru juga memberikan motivasi kepada peserta didik 
dengan berbagai cara seperti menggambarkan pengorbanan orangtua yang menyekolahkan atau apa yang akan diraih nanti berasal dari pilihannya saat ini.

Kegiatan inti yakni kegiatan belajar sesungguhnya yang dilakukan oleh guru dimulai dari pemaparan materi yang bersifat interaktif untuk mendorong munculnya interaksi antara guru dengan peserta didik. Kemudian guru memberikan contoh berkaitan dengan materi, jika belajar sains guru memberikan contoh dalam kehidupan sehari-hari. Guru bertanya kepada peserta didik tentang sesuatu yang tidak dipahami dari materi. Jika pelajaran berhitung guru menulis satu soal di papan tulis dengan motivasi tambahan nilai dan memberikan kesempatan untuk maju menyelesaikannya. Sebelum maju menjawab, peserta didik mengecek jawaban kepada guru. Kemudian menuliskan jawaban, selanjutnya guru membenarkan dan menjelaskan jawaban. Jika peserta didik hanya sebagian yang aktif, maka guru memberikan soal kemudian diskusi bersama teman dan dikumpul. Ketidakaktifan peserta didik karena ada yang kurang percaya diri dan ada yang kurang berminat dalam merespon materi terutama jika posisi duduk bagian belakang, ada yang bercerita dan bermain handphone. Kegiatan yang terakhir yakni guru menutup pembelajaran. Guru mengingatkan peserta didik mengenai tugas di rumah kemudian menutupnya dengan salam.

Dalam pelaksanaan pembelajaran, guru lebih menekankan pada metode pembelajaran daripada penggunaan media. Guru memilih salah satu media seperti papan tulis atau proyektor disebabkan guru terbiasa dan merasa cukup bisa menggambarkan melalui media tersebut. Guru juga melakukan pengembangan dalam metode pembelajaran yang disesuaikan dengan kondisi kelas tanpa berdampak pada kompetensi yang hendak dicapai.

\section{Penilaian Hasil Belajar}

Bichi (2017, h. 110) menjelaskan bahwa guru bertanggung jawab dalam pendidikan dan penilaiannya berfungsi sebagai salah satu cara untuk memantau dan mengatur akuntabilitas. Penilaian ini bertujuan untuk melakukan evaluasi hasil belajar melalui keputusan yang ditentukan sesuai dengan pengertian yang dikemukakan oleh Davies bahwa evaluasi merupakan proses sederhana memberikan/menetapkan nilai kepada sejumlah tujuan, kegiatan, keputusan, unjuk rasa, proses, orang, objek dan masih banyak yang lain (Dimyati dan Mudjiono, 2013). Evaluasi berupa proses yang ditempuh untuk mengetahui keefektifan pembelajaran, hasil evaluasi dijadikan sebagai perbaikan dan penyempurnaan program pembelajaran.

Penilaian yang dilakukan guru di SMAN 22 Makassar melalui empat teknik penilaian yaitu kompetensi sikap spiritual dan sikap sosial dengan cara observasi, penilaian diri dan penilaian antartema, penilaian kompetensi pengetahuan dengan cara lisan (jawaban terbuka), penugasan, tertulis (berbentuk esai, pilihan ganda, menjodohkan, benar salah dan lainnya) dan pertofolio, kemudian penilaian kompetensi keterampilan dengan cara praktik, produk, proyek dan protofolio. Nickel 
J. (2013, h. 11) melakukan penilaian keterampilan dengan cara mengumpulkan hasil karya (produk) penugasan (proyek) dan hasil kerja siswa (porfofolio). Almod $\mathrm{P}$ (2010:22) menjelaskan bahwa dalam melakukan penilaian hasil belajar harus ada rubrik penilaian yang terdiri dari proses belajar, keterampilan dan pemahaman yang dikombnasi dengan teknologi informasi. Format penilaian telah tertera pada setiap RPP yang telah dirancang sehingga guru bisa mengaplikasikan saat atau setelah pembelajaran.

\begin{abstract}
Mengacu pada kurikulum 13 bahwa penilaian dilakukan perkompetensi dasar, misalnya ada kompetensi dasar belum tuntas maka itu yang dituntaskan. Jika yang lain sudah tuntas maka fokus pada kompetensi dasar yang belum tuntas. misalnya soal nomor 1 sampai nomor 5 nanti di antara 5 soal itu yang salah hanya nomor 5 maka itu yang diujikan kembali. Nomor 1 sampai 4 tidak. (wawancara dengan Ibu Yulianti sebagai guru Pendidikan Agama Islam di SMAN 22 Makassar tanggal 10 Oktober 2019).
\end{abstract}

Hal ini sejalan dengan hasil dokumentasi dan observasi, guru akan memberikan remedial kepada peserta didik karena dua hal yaitu peserta didik yang belum mencapai kriteria ketuntasan minimal (KKM) atau peserta didik yang belum mencapai kompetensi dasar. Bila setelah penilaian ternyata ada peserta didik belum mencapai kriteria ketuntasan minimal, guru akan melakukan remedial teaching kemudian menilai kembali dengan soal yang sama atau lain mengacu pada kompetensi dasar yang belum dikuasai oleh peserta didik. Pengayaan juga diberikan untuk menambah wawasan peserta didik baik telah mencapai ketuntasan kriteria minimal atau mencapai kompetensi dasar. Remedial dan pengayaan ini dilakukan sesuai dengan kesepatakan antara guru dengan peserta didik.

Guru dapat memilih cara penilaian agar bisa mengukur pemahaman dan perkembangan dari peserta didik. Ada peserta didik yang lebih menyukai kuis, namun ada juga yang menyukai tugas tambahan. Tergantung guru dalam mengembangkan cara penilaian dengan mempertimbangkan kefektifan dan tujuan yang ingin dicapai. Pelaksanaan evaluasi yang dilakukan di SMAN 22 Makassar sudah baik, akan tetapi belum optimal. Bukan dilihat dari proses evaluasinya akan tetapi dari hasil pencapaiannya. Ada beberapa peserta didik yang belum tuntas belajar berarti masih diperlukan remedial. Bahkan dari remedial yang dilakukan masih ada juga peserta didik yang belum tuntas.

\title{
PENUTUP/SIMPULAN
}

Berdasarkan hasil penelitian dan pembahasan dapat disimpulkan bahwa kinerja guru dalam proses pembelajaran di SMAN 22 Makassar meliputi perencanaan, pelaksanaan dan evaluasi hasil belajar termasuk dalam kategori baik dibuktikan dari perencanaan sesuai dengan standar proses, pelaksanaan sesuai 
dengan RPP yang dibuat dan dapat dikembangkan berdasarkan kondisi kelas serta evaluasi yang dapat diketahui sejauh mana perkembangan peserta didik.

Implementasi Full Day school di SMAN 22 Makassar mengalami perubahan dari ketentuan Permendikbud dari segi jadwal sekolah yakni hari sekolah mulai hari senin sampai jumat dari pagi hingga sore dengan alokasi waktu 40 jam seminggu, sekolah melakukan penambahan waktu istirahat dari ketentuan yang berlaku dengan harapan ketika dalam kelas mereka sudah siap menerima pembelajaran tanpa harus didesak oleh waktu yang minim.

Upaya efektif untuk mengoptimalkan kinerja pembelajaran di SMAN 22 Makassar dilakukan oleh guru dan sekolah. Guru menanamkan pemahaman tentang pentingnya belajar untuk meraih harapan masa depan, memberikan motivasi dan memvariasikan metode pembelajaran dalam kelas, jika siang hari biasa melakukan outing class dengan memanfaatkan fasilitas sekolah. Sekolah membantu guru melalui aturannya untuk menertibkan pembelajaran baik guru atau peserta didik. Adanya piket PBM (proses belajar mengajar) untuk mendisiplinkan guru dalam menjalankan tanggung jawab dalam kelas. Jadwal dan kegiatan sekolah terkontrol dengan baik. Pada siang hari, kepala sekolah juga melakukan tawaf (keliling sekolah) untuk melihat berjalannya aktivitas pembelajaran. Semua elemen sekolah memberikan kontribusi agar tercipta lingkungan sekolah yang kondusif dan nyaman bagi peseerta didik.

\section{DAFTAR PUSTAKA}

Abuddin Nata, Manajemen Pendidikan Mengatasi Kelemahan Pendidikan Islam di Indonesia, (Jakarta: Prenada Media, 2003), h. 95-96.

Almond P. (2010). Technology-Enabled and Universally Designed Assessment: Considering Access in Measuring the Achievement of Student with Disabilities A Foundation for Research The Journal of Tecnology. Learning and Assessment 10(5).

Anwar, Muhammad. (2018). Menjadi Guru Profesional. Jakarta: Prenadamedia Group.

Ardy Wiyani, Novan. (2015). Etika Profesi Keguruan. Yogyakarta: Gava Media.

Dimyati dan Mudjiono. (2013). Belajar dan Pembelajaran. Jakarta: PT Rineka Cipta.

Echols, John M. dan Hasan Shadily, Kamus Inggris Indonesia (Jakarta: Gramedia, 1983), h. 260

Hakin, Adnan. (2015). Contribution of Competence Teacher (Pedagogical, Personality, Professional Competence and Social) On the Performance of Learning, The International Journal Of Engineering And Science 4 (2).

Ismail, Muhammad Ilyas. (2013). Guru Sebuah Identitas. Makassar: Alauddin University Press. 
Kasmawati. (2014). Pengembangan Kinerja Tenaga Kependidikan. Makassar; Alauddin University Press.

Nickel J. (2013). Formative Assessment and Synthesies in Reflection Journals. Reflection Journals. Volume 6(3).

Ningsih, Sulandari. (2016). Hubungan Pelaksanaan Full Day School Dan Boarding School Dengan Pembentukan Karakter Pada Siswa Kelas Xi Man 1 Surakarta Tahun 2016/2017. Jurnal Global Citizen, 2(2), 53-64.

Rusman. (2017). Belajar Dan Pembelajaran Berorientasi Standar Proses Pendidikan. Jakarta: Kencana.

Ismail, Muh. Ilyas. (2010). Kinerja dan Kompetensi dalam Pembelajaran. Lentera Pendidikan 13(1), 44-63.

Sanjaya, Wina. (2015). Perencanaan dan Desain Sistem pembelajaran. Jakarta: Prenadamedia Group.

Peraturan Menteri Pendidikan dan Kebudayaan No. 23 tahun 2017 tentang Hari Sekolah.

Kementerian RI. (2007). Al-Qur'an dan Terjemahnya. Bandung: Syamil Quran.

Tahir, Yusuf. (2012). Anomali Reformasi Penyelenggaraan Pembelajaran Di Indonesia, Lentera Pendidikan 15(1).

Undang-Undang RI No. 20 Tahun 2003 tentang SISDIKNAS.

Warsito dan Asrowi. (2017). Effectiveness of Social Science Learning Based on Noble Values of Ki Hajar Dewantara's Teaching to Strengthen the Students' Character. International Journal of Active Learning 2 (1).

https://m.detik.com/news/berita/d-3529410/mendikbud-sekolah-8-jam-bukanlahfull-day-school diakses 10/3/2019.

https://www.change.org/p/kami-tolak-pendidikan-full-day-sehari-penuh-diindonesia-kemendikbud-ri diakses 10/3/2019. 